\title{
Post-socialist energy reforms in critical perspective: entangled boundaries, scales and trajectories of change ${ }^{1}$
}

\author{
Stefan Bouzarovski (s.bouzarovski@gmail.com) ${ }^{2}$
}

\footnotetext{
${ }^{1}$ A later version of this paper has been published as Bouzarovski S (2010) Post-communist energy reforms in critical perspective: Entangled boundaries, scales and trajectories of change. European Urban and Regional Studies 17: 167-182.

${ }^{2}$ Stefan Bouzarovski is also known as Stefan Buzar. Part of the background research for this paper has been supported by the Ministry of Education, Youth and Sports of the Czech Republic (project no. MSM0021620831: 'Geographic Systems and Risk Processes in the Context of Global Change and European Integration'). Additional work was undertaken as part of an External Professorship at the Institute of Geography, University of Gdansk, Pilsudskiego 46, Gdynia, Poland. All errors and omissions should be attributed solely to the author.
} 


\title{
Post-socialist energy reforms in critical perspective: entangled boundaries, scales and trajectories of change
}

\begin{abstract}
Despite its extensive political, economic and social ramifications, the process of energy sector transformation in the post-socialist states of Eastern and Central Europe (ECE) and the Former Soviet Union (FSU) has received very little theoretical attention to date. In this paper, I draw attention to the multiple ways in which the energy reform experience of the past two decades has undermined established understandings of scale, reform trajectories and national boundaries in this part of the world. With the aid of concepts developed in Science and Technology Studies (STS) and Actor Network Theory (ANT), I discuss the ability of energy relations and interdependencies to create material and political 'topologies' and 'entanglements' of power in post-socialism. This exploration is grounded in a discussion of the tensions between the legacies and path-dependencies inherited from the centrally planned economy, on the one hand, and the neoliberal project for energy sector reconfiguration that became the dominant reform paradigm in the early 1990s, on the other.
\end{abstract}

Key words: energy policy * post-socialist transformation * path-dependency ${ }^{*}$ scale $*$ energy security

In January 2009, halfway through one of the coldest winters in recent history, 18 European countries found that their regular supply of Russian piped gas had been interrupted. As a result of a long-standing bilateral gas pricing and payment dispute between the Russian gas monopoly Gazprom and the Ukrainian Naftohaz, the former decided to close the valves of the pipelines delivering gas to the latter. This was soon followed by the complete cessation of all remaining overland Russian gas exports transiting Ukraine en route to other European countries. What seemed like a minor squabble between two post-Soviet neighbours was quickly transformed into a fully-fledged energy crisis affecting large swathes of the continent. With gas pressure dropping rapidly across national boundaries, the governments of the affected states scrambled to find alternative sources of energy, or limit their domestic consumption. However, the social, economic and political effects of the crisis were only alleviated in the relatively small group of countries, mainly in Western Europe, which had the ability to activate alternative import routes and supply options. Many East Central European (ECE) states - traditionally heavily reliant on Russian gas imports via Ukraine - were forced to stop supplying gas to industrial and residential consumers altogether, while closing public buildings. Slovakia, Romania, Bosnia and Bulgaria were particularly badly hit; the former two even declared national states of emergency (Euractiv.com, 2009; BBC News, 2009).

Rarely has a single event brought home - both literally and figuratively - the deleterious consequences of post-socialist transition in such a powerful way. The gas crisis highlighted the infrastructural dependence of ECE countries on political developments, economic relations, hydrocarbon resources and energy transit pathways located in the former Soviet Union: a clear legacy of communist central planning, which is still present in the region despite 20 years of post-socialist transformation. It also demonstrated that the European Union is unable to act as a collective entity in ensuring the security of energy supplied to its member states, mainly thanks to the lack of a common energy policy, broad-level political 
consensus and institutional framework to deal with the multiple challenges associated with importing gas from Russia. And, if we accept that socio-technical failures such as this are usually symptoms of wider systemic problems at the interface between state policy and infrastructural assemblages (see, for example, Berkhout et al., 2004) it can be argued that the crisis publicly exposed the growing gap between the neatness of the neoliberal theoretical prescriptions for post-socialist energy sector liberalisation, unbundling and privatisation - on the one hand, and the messy realities of day-to-day reforms, on the other.

It is the realities of post-socialist energy transformation that I discuss in this paper. Based on the premise that the energy crisis was the culmination of a broader Russo-Ukrainian conflict related to the restructuring of the hydrocarbon industry, international power relations, and the path-dependencies and rigidities associated with gas export pipelines, I draw attention to the multiple ways in which the two decades-old experience of energy reforms in Eastern and Central Europe (ECE) and the Former Soviet Union (FSU) has destabilised antecedent understandings of scale, reform trajectories and national boundaries in post-socialism. By elaborating a critical perspective on the two decades of legal and operational energy sector reconfigurations that they have undergone (to various degrees and along divergent paths), I identify some of the underlying political, economic and spatial features of the post-socialist transformation process during the past 20 years. In particular, I focus on the theoretical significance of the energy reform project in ECE and FSU, with respect to the challenges, tensions and discrepancies stemming from the creation of a new set of socio-technical assemblages under conditions of economic and political transition.

Despite their obvious political significance and ability to attract constant public interest, energy policies in post-socialist states have received surprisingly little critical attention to date. Although a wide range of economists, engineers, environmental scientists and other energy specialists have been active in this part of the world ever since the fall of communism (if not before), most of the work that has been published in the relevant fields tends to be highly technical, reductionist, and practice-oriented. It is difficult, if almost impossible, to find scholarship that sees post-socialist energy sector reforms through a wider conceptual lens. Given such lacunae in the academic and policy literature, as well as the fact that the past two decades of reform experience already provide a substantive body of evidence that can be used as a basis to evaluate the outcomes of reform strategies adopted during the post-socialist transformation, this paper critically appraises some of the wider spatial implications of the energy restructuring process in ECE and FSU, with the aid of concepts developed in Science and Technology Studies (STS) and Actor Network Theory (ANT). Notwithstanding their growing popularity within social science during the last two decades (see, for instance, Callon, 1986; Bijker, 1993; Murdoch, 1998; Latour, 2005), I believe that these two approaches can offer an innovative and integrated analytical framework for interpreting the joint social and infrastructural construction of energy restructuring policies, thanks to their ability to straddle disciplinary boundaries and undermine established understandings of the material, technical and the social (Law and Bijker, 1992; Barry 2001).

The core part of the paper contains three sections, each of which treats a different temporal and spatial dimension of energy policy in post-socialism. The first of the three is a brief account of some of the ways in which structural legacies and path-dependencies inherited from communism shaped, and were shaped by, the neoliberal project for energy sector reconfiguration that became the dominant reform paradigm in the early 1990s (see also Pickles 2010). The second section outlines the tensions associated with the translation of these relations into day-to-day decision-making practice. The third, and final, part of the paper 
concentrates on the ability of post-socialist energy interdependencies to create material and political 'topologies' and 'entanglements' of power across national boundaries. Here, I argue that the relationships between spatial formations, energy flows and post institutional transformation in ECE and FSU have undermined existing national, sectoral and scalar boundaries. Before delving into such discussions, however, I provide a brief outline of the theoretical background to STS and ANT concepts that are employed in the paper.

\section{Energy flows and networks of power through the lens of science and technology studies}

Socio-technical networks are becoming an increasingly important object of study across a number of different disciplines. The last 10 years have seen a proliferation of academic research focusing on the multiple mechanisms that drive the creation and operation of information technology, economic and technical networks (see, for example, Hetherington and Law, 2000; McFarlane and Rutherford, 2008). However, such work has yet to be undertaken in the domain of energy infrastructure, which is one of the most powerful embodiments of entangled webs of interaction spanning multiple contexts and scales. The lack of expert attention in this field is all the more surprising in light of the fact that the spatial unevenness of development patterns associated with networked infrastructures for energy production, consumption and distribution has also been shown to be constitutive of wider dynamics of social and spatial inequality (Graham and Marvin, 2001).

This recent lacuna in scientific interest should not be taken to imply that energy networks have failed to receive scholarly attention in the past. Most notably, Thomas Hughes' (1993) study of the history and progress of electrification in Europe and North America is still regarded as one of the pivotal contributions in the STS domain. Through a comparative study of Germany, Britain and the US, his research has been instrumental in helping to explain how different combinations of legal, institutional and spatial factors have produced varying regimes and patterns of electricity use and regulation in different geographical contexts. Besides providing a comprehensive diachronic overview of the formative stages of electricity network development, Hughes' work has also formulated several new theoretical concepts, including the idea of technological 'momentum': which is seen as the amount of inertia in a networked system, stemming from the power of vested interests possessed by the various political, economic and social actors embedded in it, as well as the number and influence of its contributors.

In a broader sense, the performance of political power in relation to energy infrastructures would be impossible without the construction of 'technological frames': heterogeneous entities that belong to both the cognitive and the social domain, involving, inter alia, exemplary artefacts, cultural values and goals, scientific theories and tacit knowledge (Bijker 1993). Technological frames are also inherently fluid, thanks in part to being created through dynamic relations among different actors. However, considering that one of the frames' primary purposes is to structure and direct further interaction, they eventually decrease the multiplicity of functions and meanings associated with a particular artefact. Through this process, they augment, to use Hughes' (1993) language, its technological momentum. In such conditions, the stability of a technological frame depends on the 'impossibility it creates of returning to a situation in which its [current form] was only one possible option among others' (Callon, 1992: 89). The likelihood of future technological change is shaped by the frame's interpretive flexibility (Orlikowski, 1992; Brey, 2003; Cadili and Whitley, 2005), which allows for different interpretations of its functional, cultural and social features (Avgerou, 2002). 
Unfortunately, most theorists and practitioners have had very little to say on the subject. One of the very few exceptions is provided by Susan Leigh Star's (1999) work on the methodological considerations involved in researching the design practices and social implications of large-scale infrastructure networks. Having pointed out that infrastructure is both 'relational' and 'ecological', since it becomes 'real' only with respect to organised practices, and has different meanings and functions in different contexts, she identifies a number of ubiquitous features possessed by such systems, including the fact that they are socio-technically embedded, transparent, and have a particular reach or scope. Star's analysis has been applied to different contexts mainly thanks to her exploration of the different ways in which infrastructure systems 'are sunk into and inside of other structures, social arrangements, and technologies', while wrestling 'with the inertia of the installed base' (Star, 1999: 381-382). In many ways, such work has formed the basis for subsequent explorations of the relationships between urban governance and energy infrastructure (see, for example, Bukeley and Betsill, 2003; Monstadt, 2007; McFarlane and Rutherford, 2008), as well as the manner in which economic systems and practices themselves are predicated on the establishment of particular socio-technical norms and relations in the energy sector (see Mitchell, 2008).

The inscriptions of technological frames in regional 'landscapes of power' has been also been studied in the post-socialist context, as demonstrated by O'Lear's (2004) research on the social, economic and spatial impacts of oil export pipelines. She is one of the few experts who has examined the multiple ways in which such infrastructures are able to attract international financial and political support, while shaping the everyday lives of local populations in affected countries. Drawing upon a case study of the Baku-Tblisi-Ceyhan (BTC) pipeline through Azerbaijan and Georgia, she has been able to thrash out some of the differences and similarities between the two countries' perceptions of this development. Despite the widely divergent concerns and expectations of Azerbaijani and Georgian residents vis-à-vis BTC, O'Lear finds that both states have used the pipeline as a means of forging political links with state and corporate actors beyond their national boundaries. Therefore, she argues, BTC has deeply affected the dynamics of power in the countries and locales along its route, often to the detriment of local populations. She underlines the spatial entanglement of private and public interests in the development of socio-technical networks in this part of the world.

Still, the question as to how energy infrastructures and flows in post-socialism themselves create broader power relations is still open. A useful starting point from a different geographical context may, however, be provided by Bennett's (2005) examination of underlying factors and conditions that led to the 2003 North American blackout: she uses the Deleuzean concept of 'assemblage' to develop an explanatory framework for the diverse ways in which the power grid's constitutive elements interact to form de-centred webs of agency. Her work operates with many of the key tenets of Actor Network Theory (ANT): a theoretical approach, initially stemming from STS, which argues in favour of considering material and semiotic 'actants' (which is argued to be a less anthropocentric term than 'actor') under a common conceptual umbrella. ANT sees the world as a collection of fluid, heterogeneous webs of activity which are constantly being reinforced and performed through the circulation of 'immutable mobiles': hybrid objects that are presentable, readable and combinable to an extent that allows information to be effectively exchanged among human and non-human agents (see Latour, 1999; Buck and Shahrim, 1999; Sarker et al. 2006). ANT has been applied to the study of a diverse range of subjects, ranging from the societal dynamics of technical 
innovation, to the grassroots creation of global peasant movements (see, for example, Callon, 1986; Sarker et al., 2006; Routledge, 2008; Bouzarovski, 2009a).

It should be noted that ANT's de-centred view of agency has been accused of failing to consider the ethical implications of moving away the onus of responsibility for action away from human subjects, in addition to 'flattening out' inherent inequalities in access to resources and power among different actants (for a wider discussion, see Castree, 2002). Nevertheless, together with STS, it can provide a useful explanatory framework for interpreting the dynamics of social and political power that underlie the evolution of energy networks in postsocialist societies. This is because both approaches emphasise the contingent, interwoven and dynamic nature of socio-technical entanglements in the production of infrastructure networks.

ECE and FSU societies have experienced the imposition of one technological frame on another, bringing with it an entirely new set of dynamics of technology transfer, standard setting and political power. In light of the demonstrated advantages of both paradigms, unpacking such processes through the lens of STS and ANT can lead to a conceptualisation of post-socialist energy circulations not just as technical objects that are borne out of particular political-economic conditions, but rather as active agents in the formulation of national policies and development patterns. This issue has a pronounced geographical dimension, since, as demonstrated by O'Lear's (2004) study cited above, energy infrastructures may project the underlying socio-technical matrices of their constituent material flows into the political spaces and territories that host them. Interpreting post-socialist energy reforms through such a theoretical framework can also help us understand the broader dynamics of power implicated in the production and articulation of such networks, especially since it remains unclear to what extent the agency of energy infrastructures stems from power dynamics contained in the materialities of energy flows themselves (as may be suggested by accounts of power by authors such as Manuel Castells) or whether it is a purely relational effect, whereby such agentic capabilities are a product of the infrastructures' interaction with other socio-political contingencies (which would be a more Deleuzian reading of power).

\section{Creating a technological frame: legacies of communist central planning in the energy sector}

The principal shared feature of the energy sectors of all post-socialist states - and indeed the underlying reason for treating them under a common umbrella in an article like this - is the relatively common set of organisational and technical features that they inherited from the centrally planned economy. Decades of communist rule imposed a specific technological frame in the energy sectors of former Eastern bloc countries, involving development and management policies that were predicated on the wider socio-economic purpose of energy operations and activities, the decision-making practices that governed energy enterprises, as well as the spatial patterns of energy production and consumption. When communism fell, ECE and FSU states possessed a common group of cultural and political legacies, economic interests and technological frames - to use STS language - that had become institutionally entangled with national and local state policies.

Although there is a significant literature on this subject (see, for example, Dienes, 1979; Lewis, 1979; Pallot and Shaw, 1982; Crnobrnja, 1991; Gray, 1995; Brendow, 2001; von Hirschhausen and Wälde, 2001), it is worth pointing out once again that under communism, energy policy provided the logistical basis of the centrally planned economy, while helping legitimate the political order of state socialism. Indirect subsidies that led to the under-pricing 
of energy services were the cornerstone of state industrial development plans and social support frameworks under this period. They were supported by a constant emphasis on expanding the resource base and extracting hydrocarbon resources from a limited number of sites, mainly located in the FSU. As such, they helped support one of the key operating principles of the Soviet model of industrialisation, which aimed to achieve self-sufficiency in basic goods and services, such as energy (see, for example, Dienes and Shabad, 1979). The state also sought to maximise the mass provision of networked energy services for households and industry, reaching record levels of access to electricity, piped gas and heat. Energy companies were monopolies run by the state, as a single enterprise would be responsible for all operations in a given sub-domain of the energy sector (Gray, 2005).

The construction of district heating systems was another clear component of the technological frame of the centrally planned economies' energy sectors. In yet another ideologically-driven collusion of social, energy and urban development policies, Soviet planners built large, centrally controlled networks for the production, transmission and distribution of heat in densely built-up areas. The hubs of such systems consisted of energy plants that burnt oil, gas or coal in order to produce hot water and steam that was then distributed to residential users (Velody, 2003). The heating networks' unwieldiness and inflexibility meant that they had to be mainly built in urban areas, thus becoming an inseparable component of Soviet microraions with prefabricated multi-storey apartment blocks. But although this form of energy represented a relatively affordable and equitable method of energy provision, the systems were plagued by major technical and management difficulties. Apart from the outdated technologies and above-average heat losses in the plants and transmission networks themselves - whose locations in urban areas were often marked in mid-winter thanks to the melted snow trails above them -the largest problems began when the heat reached the apartment buildings (Ürge-Vorsatz, 2006). Individual flats or housing blocks were not equipped with meters or thermostats, creating a situation in which individual householders had no information or incentive about the regulation of their heat consumption. Moreover, the pipes were arranged in a vertical, rather than a horizontal way, which meant that the provision of heat to a given flat could not be controlled at a single point. One consequence of this policy was that each apartment was colder than the one through which the pipes had passed before (Chandler, 2000; Velody, 2003).

In this context, it is worth mentioning yet another clear element of central planning's structural legacies in the energy sector: large scale nuclear and hydro power projects. By the end of the communist era, almost every ECE and FSU country had at least one nuclear reactor or plans to build one, with the notable exception of Poland where staunch local opposition had forced the government to halt the construction of a half-finished plant at Żarnowiec in the north of the country, with the reactors being subsequently sold off to Finland and Hungary. Nuclear stations were constructed using three basic reactor types - the RMBK, VVER 440 and the VVER 1000 - all of which were later shown to be inherently unsafe due to, inter alia, the inadequate containment of the core and low levels of automation (Chandler, 2000). The development of large-scale hydropower was also a clear communist policy priority, as evidenced by the record-breaking size of dams on the Volga, Yenisei and Angara rivers in Russia, as well as smaller schemes in present-day Latvia, Bosnia, Serbia and the Czech Republic. Nevertheless, the development of this technology hardly reached the full potential of the underlying natural resource in many ECE countries, due to, inter alia, the lack of investment capital (Bouzarovski, 2009b). 
The fact that the institutional, ideological and political underpinnings of communist central planning in the energy sector were relatively uniform across the entire Eastern bloc should not be taken to mean, however, that the patterns of energy production and consumption were equally similar. One of the most significant differences between the ECE and FSU regions related to the predominance of gas and oil in the total primary energy supply of the latter, vs. coal in the former. In the main, this discrepancy stems from the resource base of the two geographical realms: Russia and Central Asia contain some of the world's largest oil and gas reserves, while coal is abundant in many Central European and Balkan states. Moreover, the Soviet Union became less and less willing to provide subsidised oil and gas to Eastern Europe after the energy crises of the 1970s, which increased the world market price of these resources. Exporting oil and gas to Western European states helped the Soviet Union earn badly needed hard currency (Stern, 1980).

In order to compensate for the potential loss of geopolitical influence brought about by the ever increasing role of domestically mined coal in the energy balances of ECE states, the Soviet Union ensured that it was the sole provider of any remaining non-coal resources in their total primary energy supply. The realisation of this policy objective was aided by the creation of economic structures that relied on the prioritisation of cheap, universally available hydrocarbons in the industrial development of such countries, alongside the construction of energy transport infrastructures that cemented their dependence on the Soviet oil and gas resource base. As a result, all major international oil, gas and electricity networks in this part of the world were built in an East-West direction, connecting Soviet oil and gas fields with consumption centres in Eastern Europe. The Soviet Union could exercise firm political and economic control by deciding when and how to regulate energy flows 'satellite' ECE states. This is illustrated by the fact that, in 1989, the ECE region as a whole (excluding the three Baltic republics) was dependent on the Soviet Union for 31 per cent of its total primary energy supply (TPES), including extremes of 68 per cent in Bulgaria and 48 per cent in Hungary. Coal, which accounted for one half of TPES in ECE, was the only fuel that provided some measure of energy independence: ECE relied on the Soviet Union for three quarters of its oil demand, and virtually all of its gas imports (Dienes et al., 1994: 206-207).

Still, the clearest and most widespread legacies of communist energy policies across the entire ECE and FSU region relate to the extremely high energy intensities of their economies. This is illustrated by the fact that ECE states required more than double the amount of energy to produce the same unit of economic output generated by their neighbours in Western Europe (Dienes et al., 1994: 206). Similarly, Russia needed 42 Megajoules to produce the GDP equivalent of 13 Megajoules in the United States (Chandler, 2000: 7). High energy intensities were related to the low efficiency of energy extraction, conversion, transport and consumption across the region. Aside from low energy prices, the lack of technology transfer was possibly the main culprit of this phenomenon: despite the record number of engineers and scientists, the centrally planned economy did not have the 'interpretive flexibility' to develop and disseminate their innovations (Chandler, 2000).

When coupled with the economic and political isolation of Eastern bloc countries, these circumstances meant that suboptimal technological solutions were often used in the construction, operation and maintenance of industrial plants, technical artefacts, and commercial, public and private buildings. Thus, despite being located in, on average, a significantly more compact building, a Soviet dwelling needed two to three times more energy to heat the equivalent amount of space possessed by a North American home. This was partly a result of the fact that FSU apartments often lacked basic thermal efficiency 
measures, having been built in line with standards that were generally 15 times lower than the those enforced by Western European states (Dienes et al., 1994: 24). Also influencing the high energy intensities of ECE and FSU economies was the fact the communist industrial system was primarily geared towards iron and steel, chemicals, cement and aluminium production, which distorted the economic structure and made it energy intensive by definition. Adding to these issues was the existence of 'soft budget constraints', which provided incentives for enterprises to use energy in larger quantities, rather than through more efficient methods (see Kornai, 1986; Ürge-Vorsatz et al., 2006).

The environmental consequences of these practices were disastrous, in the least. Without wishing to elaborate in further detail the relatively well-known and extensively-discussed impacts of nuclear power development in the Soviet Union or coal extraction and burning in Central Europe - to name the two most prominent examples - specific techno-natures were created by communist-era regulation of energy activities (also see Waller, 1998). Seen in the context of its environmental implications, the technological frame that underpinned the energy sectors of centrally planned economies can be conceptually expanded to include not only the hybrid networks of policies, ideologies, practices, infrastructures and technologies which characterised the translation process that led to its creation, but also the agency of nonhuman environmental 'pollutants' that aggravated the health of, inter alia, human populations across the ECE and FSU region (see Pavlinek and Pickles, 2000). It also becomes clearer how and why the same technological frame never fully managed to stabilise itself during communism.

\section{Enfilades of practice: the institutional aspects of energy reform}

The fall of communist rule exposed the infrastructural, social and technical threads of the energy networks created by the centrally planned economy to an entirely new set of conditions. This is because the factors that sustained the previous energy system were either deeply transformed or no longer existent and the geopolitical and ideological ties binding the skein of energy relations between FSU and ECE were broken, leading to the removal of energy price subsidies and the disruption of trade patterns. The FSU itself quickly disintegrated amidst a series of rapid political and economic developments, creating entanglements of resource dependencies in geopolitical settings where they did not exist before. As a whole, these events warranted a new response to the political and economic realities of post-socialism, involving a deep restructuring of the energy sector. In other words, there was a need for a re-interpretation of the technological frame created under communism.

Just like other parts of the economy and society, neoliberal principles provided the template for sector reforms in this domain. Their translation into energy policies was based on the Anglo-Saxon experience of 'deregulation' in the 1980s. It involved the dissolution of former vertically and horizontally integrated energy companies into separate entities responsible for the generation, transmission and distribution of energy, as well as the creation of a new legal framework that would allow for energy markets to be opened and energy to be traded as freely as possible. It was also foreseen that energy companies would eventually be privatised, preferably via direct sales to foreign investors who could introduce new capital and management skills to them (Gray, 1995; Stern, 1998; EBRD, 1999; Brendow, 2001; Åslund, 2006). The ultimate purpose for, and justification of, all such policies was to allow for energy enterprises to compete with each other in a market-based environment, where prices would reflect long term marginal costs. In their most narrow form, they were primarily meant to be applied to electricity operations - where there was a longer experience of regulating utilities 
through this approach based on past UK and US policies - though it was expected that the same set of principles could also be implemented in the oil, gas and district heating sectors in a modified form (Hughes, 1991; World Bank, 1999; Kennedy, 2002; Brendow, 2003).

Two decades later, there is little doubt that the real-life trajectories of energy restructuring have differed significantly from their theoretical prescriptions. Even the leading Central European 'reformers' such as Poland, the Czech Republic, Slovakia and Hungary have been reluctant to unbundle parts of their energy sectors (especially oil and gas) and open them to competition (World Bank, 1999; Kopačka, 2000). Also, levels of market opening in national electricity markets - expressed through the percentage of consumers who are given the choice of freely choosing their electricity supplier - have remained low across ECE, not to mention the FSU (Bouzarovski, 2009b). In many countries, especially in the Baltic states, there are defacto national monopolies in this domain, as the markets are very small. Despite expressing a declarative commitment to undertake it as quickly as possible, Balkan and FSU states have been among the most reluctant to institute neoliberal energy restructuring; in some of the cases where reform activities in such countries were attempted during the 1990s, they were accused of lacking transparency and/or falling victim to vested interests (Rutland, 1997; Anex, 2002; Jørgensen, 2002). As far as privatisation is concerned, there has been a patchwork of policies and outcomes across the region: even though many electricity generation plants and distribution companies have been bought up by private investors throughout ECE and even the FSU, the state has nonetheless retained a significant presence in the ownership of energy enterprises throughout the region. This has mainly been true in the oil and gas sectors, although it often pertains to electricity generation and distribution as well; the Czech Republic, Slovenia and, to a lesser extent, the Baltic states are notable examples (Kočenda and Cábelka, 1999; Filippini et al. 2004; IEA, 2005, AEA, 2009).

Despite the slow overall 'progress' of energy sector reorganisation - at least in terms of the steps warranted by the neoliberal approach - it would be incorrect to say that the postsocialist transformation has not been accompanied by significant energy efficiency improvements, at least as far as ECE is concerned. A number of authors have argued that this was aided by the implementation of rapid price rebalancing and energy liberalisation in such countries (Chandler, 2000; Cornillie and Frankhauser, 2002). They claim that the establishment of cost-based price signals - accompanied by the introduction of energy metering and, more broadly, a market-based regulation in the energy sector and the wider economy - has increased the incentives for energy companies, industrial enterprises, smalland medium-sized businesses and households to become more frugal about their energy use, and to invest in energy efficiency improvements. The intensification of technology transfer has also played a role in this process, leading to less energy-intensive methods for resource extraction, energy conversion, industrial production and building design. There has also been a major replacement of the stock of appliances and cars, even though energy efficiency gains in these domains have been offset by the significant growth in the absolute level of consumption as car and appliance ownership has increased.

In the EU accession states of ECE, the move towards more efficient energy technologies has been aided by a wide array of policies warranted, inter alia, by European legislation, including labels, standards, subsidies and even direct state-sponsored programmes for the improvement of supply- or demand-side efficiency in various sectors of the economy. In light of such circumstances, it comes as little surprise that countries like Poland, the Czech Republic, and Slovakia have become world champions in reducing the energy intensities of their economies in a very short space of time. Most notably, Poland managed to almost halve 
the energy inputs required per unit of economic output in the first fifteen years of the transformation process (Bouzarovski, 2009b). However, the fact that energy intensities have come down more or less throughout the region attests to the fact that possibly the greatest gains in the energy efficiency of economic outputs has come from deeper trends of economic restructuring, especially in terms of the downsizing and closure of large industrial enterprises and the movement towards service activities that require smaller energy inputs per unit of economic output (Lackó, 1997; EBRD, 2001; Cornillie and Frankhauser, 2002)

One of the major oversights of the enfilade of practice foreseen by the neoliberal attempt to impose a new technological frame on the post-socialist energy sector relates to the relative neglect of what Ürge Vorsatz et al. (2006) term 'the positive legacies' of communist central planning. In the main, this pertains to the particular nature of transport systems and urban morphologies, as ECE and FSU alike inherited cities with compact and densely-built up residential structures, characterised by an extremely high reliance on public transport: both features are generally seen as more favourable from the perspective of urban environmental sustainability. District heating networks have also been identified as an environmentally and economically beneficial structural legacy inherited from communism; a number of authors point out that such systems have the potential to deliver efficient, equitable and environmentally sustainable energy services if they are managed properly (Kazakevicius, 1998; Brendow, 2003; Velody, 2003).

It appears that many of these and other opportunities for 'leap frogging' towards more efficient energy operations - including the benefits of integrated settlement planning and the traditionally low rates of individual consumption at the household level - have been missed in many ECE states, as a result of the rapid application of one-way neoliberal reform policies. In particular, there is a danger that post-socialist countries will be unable to capitalise on the environmental and energy consumption benefits of well-developed public transport networks within compact urban environments as a result of widespread trends of suburbanisation (often indirectly or directly supported by the state) as well as the movement towards automobility. Ürge Vorsatz et al. (2006) point out that the more 'slowly transforming economies' in the FSU may be better placed to capitalise on such opportunities, if policy-makers at different scales - including not only the local level but multilateral financial institutions as well - are in a position to recognise and implement alternative trajectories of energy restructuring and economic change, sensitive to the multiplicity of policy outcomes and local circumstances. They also emphasise that the oft-neglected process of cultural and behavioural change in postsocialism is likely to slow down the decrease of energy intensities even if the 'most radical policy, legislative and institutional reforms' are to be implemented in ECE and FSU alike.

\section{Destabilising national, sectoral and scalar hierarchies: the emergence of new topologies of power}

Aside from altering the economic and infrastructural underpinnings of energy sector operations in ECE and FSU, the post-socialist transformation has also introduced a entire new range of geopolitical interests and power relations to this domain, thanks to, among other developments, the opening up of energy markets in Russia and Central Asia to foreign investment and international trade, and the rising demand for natural gas in Western Europe. The spatial locations of energy generation and extraction facilities, transit networks and consumption centres have gained more importance than ever, as competing interests have sought to direct and shape energy flows to their own advantage. A specific dynamic of power has emerged at the interface between the FSU and the European Union, largely thanks to the 
existence of an energy producer-consumer relationship that allows energy resources and services to flow between the two realms. ECE, as a transit space with a significant need for infrastructural expansion and upgrading (as argued by Klaassen et al., 2001), has become a key territorial arena for the articulation and mediation of geopolitical force through energy networks.

Gas pipelines and electricity networks in particular embody the spatial enmeshing of international relations of power, since the commodities they carry cannot be transferred from producer to consumer without a direct physical connection fixed in space. Adding to this is the fact that 'energy is an essentially ambiguous good because it can be considered as both a genuine commodity, tradable on the basis of purely commercial considerations, as a service (for example, transportation), and as a strategic good to be used as a foreign policy tool (for example, during the oil crisis 1973-74)' (Westphal 2006: 58). One of the best examples of these circumstances is provided by the proposed Nord Stream pipeline, a joint venture between the Russian company Gazprom (with 51\% ownership), as well as Germany's Wintershall and E.ON, each with a 24.5\% stake (Emerging Europe Oil and Gas Insight, 2007). The pipeline is projected to run for $1200 \mathrm{~km}$ along the Baltic seafloor directly between the two countries, initially carrying up to $27.5 \mathrm{Bcm} /$ year (PEEE, 2007).

The Nord Stream proposal has exhibited the ability to both shape, and be shaped by, political and economic developments in the Baltic sea region and ECE more generally. Since its official announcement in 2005, the project has been met with sharp criticism by public officials in neighbouring countries, mainly due to concerns that 'it is hard to say where Gazprom ends and the Russian state begins' (Rutland, 1997: 8). Political debates about the project have often invoked questions of national security interests and ethnic identity (Browning, 2003: 45). Estimates that the projected cost of the pipeline would 'exceed by a factor of three the cost of building an overland pipeline of equivalent capacity' (Belton and Dombey, 2007) have given further credence to such fears, alongside official Russian statements such as that of President Putin, where he underlined that 'Russia should reduce its dependence on transit countries, such as neighbouring Belarus and Ukraine, to help guarantee security of energy supplies to Europe' (Buckley and Parker, 2007).

Indeed, it has often been alleged that Russia is already using its 'energy muscle' for political and economic purposes by, for example, shutting down an oil pipeline to Lithuania after a key refinery in the country was sold to a Polish company instead of a Russian one (PEEE, 2007), halting oil exports to Estonia after the recent political crisis linked to the relocation of Soviet graves, or in the aforementioned set of energy transit disputes with Ukraine (and Belarus, in 2007 - see BBC News, 2007). But some experts point out that 'in the post-Soviet era, it is rather more difficult to devise a scenario in which Russia would choose to threaten European countries - individually or collectively, commercially or politically - by threatening to cut off gas supplies' (Stern, 2002: 18), while noting that the situation may radically change once Russia improves overland gas export links to China and other large Asian markets. Still, and regardless of the final verdict on this matter, it is clear that oil and gas pipelines has been instrumentalised for the purposes of projections and relations of power among different states in the post-Soviet realm. Nord Stream not only channels power and agency along a material 'line of flight' (to use the language employed by Deleuze and Guattari, 1998), but it has also provided the arena for broader geopolitical struggles and conflicts of interest.

Post-socialist pipeline politics have also been deeply implicated in patterns of economic growth and national development. This is because different countries in ECE have taken 
individual steps to diversify their energy supply sources, in the absence of a clear international framework for the regulation of shared energy policy interests. Poland is constructing a $\$ 459$ million liquid nitrogen gas (LNG) terminal with an initial capacity of 2.5 $\mathrm{Bcm} /$ year (PEEE, 2007). In Latvia, the economy minister has suggested that the Nord Stream pipeline could include a spur to his country's planned underground storage facilities (Emerging Europe Oil and Gas Insight, 2007a; Laurila, 2003: 39). The Czech Republic also intends to connect itself to Nord Stream via a north-bound pipeline from its border to the Baltic sea, to be constructed by the German energy company RWE (Emerging Europe Oil and Gas Insight, 2007a; Hulpachová, 2007). This resembles - at least in spatial terms - an earlier project implemented by the same country, involving the construction of a pipeline carrying oil from Norway, in order to reduce its dependence on Russian oil. In Southeastern Europe, the European Union is lending heavy support to the Nabucco gas pipeline that would transport Central Asian and Middle Eastern gas from Turkey to Austria through the Balkans (Eubusiness.com, 2009; Radio Free Europe/Radio Liberty, 2009). This project's main rival is the South Stream pipeline, a Gazprom-backed initiative that would also bring Russian gas to the Austrian and Italian borders via a Balkan overland route (Radio Free Europe/Radio Liberty, 2009).

In general, the geopolitics of energy relations during the post-socialist transformation have moved most ECE states from a reactive policy regime - in which their relevant governing bodies were passive observers of, rather than active agents in, the new set of socio-technical webs developing in the region - into a proactive one, where they have taken intentional steps to create a new set of power relations and energy interdependencies. Aside from being marked by a distinct set of identity narratives, political discourses and foreign policy strategies (the exploration of which would, however, extend beyond the aims of this article), it is worth mentioning that the second stage has also created new webs of power across the postsocialist space. It has meant that the topologies, rather than the topographies of energy infrastructures have mattered in the articulation of power interests at different scales. This is evidenced by the fact that, for example, Nabucco and South Stream proposals embody mutually conflicting political relations despite traversing a similar array of countries and regions (Upi.com, 2009); a similar situation can be found in the case of Nord Stream and its rival pipeline proposal - Amber - which is supported by the Baltic states and Poland (New Europe, 2009). Thus, the pipelines are parts of different assemblages that are performed through a set of heterogeneous power topologies, despite being sited in real, topographic space.

These conditions point to another set of consequences of the post-socialist energy transformation process: the destabilisation of previously-established meanings of national boundaries and scalar hierarchies. The introduction of a new technological frame to the region's energy sector has created an emergent set of spatial, political, economic and infrastructural interdependencies between different territorial realms, rapidly transforming the importance and function of national boundaries among them. Recent developments in the Balkan region provide one of the most powerful illustrations of this dynamic: despite decades of political conflict and discord, states in the region have recently been working together in establishing regional energy co-operation frameworks, particularly with respect to the opening up of energy markets and the construction of new generation facilities (see Redorbit.com, 2005; BBC News, 2007; Energy Community Treaty, 2009). During the peak of the 2009 gas crisis, Serbia offered part of its limited gas supplies to Bosnia for free, in spite of the recent history of war and conflict between the two countries (Balkaninsight.com, 2009). Indeed, the Balkan countries affected by the gas crisis could only rely on internationally- 
negotiated solutions to resolve its effects, regardless of whether this concerned working with neighbouring countries or participating in broader efforts to resolve the Ukrainian-Russian dispute.

In their entirety, such trends illustrate that contemporary understandings of energy security in ECE and FSU, and Europe more widely, cannot be conceptually subsumed solely under a nation-state based framework as has been the case until now (for example, see Yergin, 2006; Klare, 2008). Not only have the last two decades seen a movement of energy security relations towards international and global institutions, but the household scale has gained new significance as well. The emergence of post-socialist energy poverty - a condition whereby households cannot heat their homes to an adequate level - has provided a strong impetus in this direction. In the main, energy poverty in this part of the world is the product of the rapid rebalancing of energy prices and inefficient housing stock, and may be affecting millions of households in the poorer transition states (Kovačević, 2004; Lampietti and Meyer, 2002; Fankhauser and Tepic, 2005; see also Round and Williams, 2010). As a problem lying at the interface of the energy, housing, health and social welfare sectors, it often arises as a result of the poor co-ordination of different public and private organisations operating in these domains (Buzar, 2005). As such, it exemplifies the need for cross-sectoral co-operation and coordination: energy is no longer an issue that can be considered in solely technical or economic terms, and in isolation from the remainder of the economy and society.

Despite the far-reaching social and health consequences of domestic energy deprivation, the scalar and sectoral expansion of energy security has mainly been felt at the international level, which has seen the creation of new policy mechanisms and strategies in response to the growing complexity of energy networks in the region. The severity of geopolitical struggles over energy supply and transit has warranted the formulation of an EU energy policy that could help co-ordinate the negotiation of conflicting energy development plans in ECE. However, such a framework is still non-existent, in spite of growing political pressure and the fact that some elements of an informal EU-wide approach already exist: for example, a formal EU-Russia energy dialogue with the aim of establishing a long-term energy partnership has been in place since 2000. According to Belyi (2003) this framework underlines EU support for Russian energy infrastructure projects necessary for oil and gas supply, while establishing 'a stable pattern for co-operation' and encouraging 'Russia to actively participate in major international multilateral frameworks' (Belyi, 2003: 352).

One of the few functioning institutional frameworks for inter-governmental co-operation relevant to the ECE region is the Energy Charter Treaty (ECT), an international agreement aimed at strengthening 'the rule of law on energy issues, by creating a level playing field of rules to be observed by all participating governments, thereby mitigating risks associated with energy-related investments and trade' (Energy Charter, 2007). However, the fact that Russia has declined to participate in this process, coupled with the geopolitical difficulties created by pipeline developments such as Nord Stream, have undermined the ability of this framework to offer a stable basis for conflict mediation in the domain of international energy conflicts.

\section{Conclusion}

When Grabher and Stark (1998) published their flagship work on 'legacies, linkages and localities' more than a decade ago, I doubt that they derived their theoretical ideas from the process of evolutionary change in the post-socialist energy sector; for one, there was not enough reform experience that could inform such a theoretical extrapolation at that point in 
time. Today, however, with almost two decades of post-socialist energy restructuring behind us, it is hard to find another triad of theoretical concepts that provides a more adequate encapsulation of the complex, variegated and dynamic set of developments in this domain of post-socialist transformation. Energy operations across ECE and FSU have witnessed an unprecedented shift in the technological frame that has governed them, involving deep-seated changes in legal frameworks, institutional structures, and decision-making practices. The continued persistence of communist era legacies, embedded in particular localities, has constrained the interpretive flexibility and increased the technological momentum of this frame in relation to the application of standardised neoliberal restructuring formulae, producing diverse development paths and reform trajectories.

Any discussion of the structural outcomes of 20 years of energy reforms in post-socialism would be incomplete without considering the broader geopolitical issues related to the involvement of energy infrastructures in the production of space. The theorisation of such objects as networked assemblages might suggest that their geopolitical agency is more clearly delineated and seems to be vested, like Weber (1968) would argue, in their very own material existence. Yet although it is almost too attractive to apply this, or Castells' (2002) analogy of networks as physical 'conduits' and circuits for the transmission of power, to interpretations of the political and economic agency of networked energy infrastructures, it is also worth considering that such systems are also expressions of broader social relations and political contingencies (as in Allen's, 2003, theorisation). Thus, in ECE and FSU alike, decisions over the location and size of energy infrastructures have been deeply implicated in local and regional patterns of economic development, the symbolic making and imagination of locales, the articulation of notions of national identity and security interests, as well as broader geopolitical developments in the region. In many ways, this conceptualisation of the political agency of infrastructural assemblages in the energy sector is closer to the relational interpretation of 'entanglements of power' offered by, inter alia, Sharp et al. (2000).

As a whole, therefore, the post-socialist transformation has destabilised international political and economic relations in the ECE and FSU region, creating new networks of power across national boundaries. By channelling such connections in materially distinct ways, networked energy infrastructures have provided an institutional pivot point for the negotiation of geopolitical relations. Through them, the process of energy sector reform in post-socialism, besides growing out of and reinforcing place-based contingencies, has become deeply implicated in the political, economic and discursive production of space. The emergence of new topologies of power has contributed to the destabilisation of scalar hierarchies and sectoral boundaries, exposing the inability of neat separations of scales of processes (Latour, 1997; Lemke, 2000) to capture the complexity of hybrid assemblages in the domain of energy operations. As such - and thanks to the ill-effects of mass infrastructural breakdowns such as the energy crisis discussed at the beginning of this paper - it has demonstrated that energy security is not and should not be a matter primarily regulated by national governments; the empowerment of a wider range of decision-making institutions, from global organisations to households, is imperative in order to ensure a sustainable energy future.

\section{References:}

AEA (Austrian Energy Agency) (2009) 'Energy in Central and Eastern Europe', Accessed on 1.5.2008 at http://www.eva.ac.at/enercee/.

Agrawal, A. (2005) Environmentality: Technologies of Government and the Making of Subjects. 
Durham, N.C.: Duke University Press.

Allen, J. (2003) Lost Geographies of Power. Oxford: Blackwell.

Anex, R. P. (2002) 'Restructuring and privatizing electricity industries in the Commonwealth of Independent States', Energy Policy 30: 397-408.

Åslund, A. (2006) 'Russia's energy policy: a framing comment', Eurasian Geography and Economics 47: 321-328.

Avgerou, C. (2002) Information Systems and Global Diversity. Oxford: Oxford University Press.

Balkaninsight.com (2009) 'Serbia gas offer warms Bosnia homes, hearts', Accessed on 01.05.2009 at balkaninsight.com/en/main/news/15923.

Barry, A. (2001) Political Machines: Governing a Technological Society. London and New York: Athlone Press.

BBC News (2007) 'Russia oil row hits Europe supply', Accessed on 8.01.2007 at http://news.bbc.co.uk/1/hi/business/6240473.stm.

BBC News (2007) 'EU rejects Balkans nuclear plea', Accessed on 13.03.2007 at http://news.bbc.co.uk/1/hi/world/europe/6445795.stm.

BBC News (2009) 'Europe homes freeze amid gas row', Accessed on 01.05 .09 at http://news.bbc.co.uk/1/hi/world/europe/7819429.stm.

Belton, C. and Dombey, D. (2007) 'Pipeline set to tighten Russian grip on energy', Financial Times 22nd May, 2007.

Belyi, A. (2003) 'New dimensions of energy security of the enlarging EU and their impact on relations with Russia’, European Integration 25: 351-369.

Bennett, J. (2005) 'The agency of assemblages and the North American blackout', Public Culture 17: $445-465$

Berkhout, F., Smith, A. and Stirling, A. (2004) 'Socio-technological regimes and transition contexts', in B. Elzen, F. W. Geels and K. Green (eds.) System Innovation and the Transition to Sustainability: Theory, Evidence and Policy, pp. 48-75. Cheltenham: Edward Elgar.

Bijker, W. (1993) 'Do not despair: there is life after constructivism', Science, Technology and Human Values 18: 113-138.

Bouzarovski, S. (2009a) 'East-Central Europe's changing energy landscapes: a place for geography', Area, in print (available online at: http://www3.interscience.wiley.com/journal/122314102/abstract).

Bouzarovski, S. (2009b) 'Building events in inner-city Gdansk, Poland: exploring the socio-spatial construction of agency in built form', Environment and Planning D: Society and Space 27: 840-858. 
Brendow, K. (2001) 'Privatising and regulating the electricity and gas industries in Central and Eastern Europe: models, status, issues ', Accessed on 10.06.2007 at http://www.worldenergy.org/wec-geis/ global/downloads/skopjemanu.pdf.

Brendow, K. (2003) 'Restructuring DH/CHP in Central and Eastern Europe: analysis and action', in W. E. Council (ed.) Towards Local Energy Systems: Revitalising District Heating and CoGeneration in Central and Eastern Europe., pp. 63-91. London: World Energy Council,.

Brey, P. (2003) 'Theorizing technology and modernity', in T. Misa, P. Brey and P. Feenberg (eds.) Modernity and Technology, pp. Cambridge: MIT Press.

Browning, C. S. (2003) 'The region-building approach revisited: the continued othering of Russia in discourses of region-building in the European North', Geopolitics 8: 45-71.

Buck, T. and Shahrim, A. (2005) 'The translation of corporate governance changes across national cultures: the case of Germany', Journal of International Business Studies 36: 42-61.

Buckley, N. and Parker, G. (2007) 'Russia to cut use of energy transit countries', Financial Times 21st January, 2007.

Bulkeley, H. and Betsill, M. (2003) Cities and Climate Change: Urban Sustainability and Global Environmental Governance. London and New York: Routledge.

Buzar, S. (2007) Energy Poverty in Eastern Europe: Hidden Geographies of Deprivation. Aldershot: Ashgate.

Cadili, S. and Whitley, E. A. (2005) 'On the interpretative flexibility of hosted ERP systems', Journal of Strategic Information Systems 14: 167-195.

Callon, M. (1986) 'The sociology of an actor-network: the case of the electric vehicle', in M. Callon, J. Law and A. Rip (eds.) Mapping the Dynamics of Science and Technology: Sociology of Science in the Real World, pp. 19-34. Basingstoke: Macmillan.

Callon, M. (1992) 'The dynamics of techno-economic networks', in R. Coombs, P. Saviotti and V. Walsh (eds.) Technological Change And Company Strategy: Economic and Social Perspectives, pp. 72-102. London and San Diego: Harcourt Brace Jovanovitch.

Castells, M. (2002) The Rise of the Network Society. The Information Age: Economy, Society and Culture. Oxford: Blackwell.

Castree, N. (2002) 'False antitheses? Marxism, nature and actor-networks.' Antipode 34: 111-146.

Chandler, W. (2000) Energy and Environment in the Transition Economies: Between Cold War and Global Warmig. Oxford and Boulder: Westview Press.

Cornillie, J. and Frankhauser, S. (2002) The Energy Intensity of Transition Countries. London: European Bank for Reconstruction and Development.

Crnobrnja, M. (1991) 'Yugoslavia's energy choices and the economic dimension ', in J. 
DeBardeleben (ed.) To Breathe Free: Eastern Europe's Environmental Crisis, pp. 169-189. Washington, D.C, Baltimore, London: Woodrow Wilson Center Press, and Johns Hopkins University Press.

Deleuze, G. and Guattari, F. (1988) A Thousand Plataeus: Capitalism and Schizophrenia. London: Athlone Press.

Dienes, L., Dobozi, I. and Radetzki, M. (1994) Energy and Economic Reform in the Former Soviet Union. London: St. Martin's Press.

Dienes, L. and Shabad, T. (1979) The Soviet Energy System. New York: V. H. Winston \& Sons, Halsted Press.

EBRD (European Bank for Reconstruction and Development) (1999) Energy Operations Policy. London: EBRD.

Emerging Europe Oil and Gas Insight (2007a) ‘Nord Stream troubles', July 2007.

Emerging Europe Oil and Gas Insight (2007b) ‘Latvia shows interest in Nord Stream’, June 2007.

Energy Charter (2007) 'Energy Charter: about the charter', Accessed on 20.05.2007 at http://www.encharter.org/index.php?id=7.

Energy Community Treaty (2009) 'Energy Community', Accessed on 2.05.2009 at http://www.energycommunity.org/portal/page/portal/ENC_HOME/ENERGY_COMMUNITY.

Eubusiness.com (2009) 'Nabucco and South Stream: two rival gas pipelines for Europe', Accessed on 26.4.2009 at http://www.eubusiness.com/news-eu/1240676222.0.

Euractiv.com (2009) 'Gas crisis gives Slovakia excuse to restart nuclear unit', Accessed on 01.05.2009 at http://www.euractiv.com/en/energy/gas-crisis-gives-slovakia-excuse-restartnuclear-unit/article-178429.

Fankhauser, S. and Tepic, S. (2005) Can Poor Consumers Pay for Energy and Water? London: European Bank for Reconstruction and Development.

Filippini, M., Hrovatin, N. and Zorič, J. (2004) 'Efficiency and regulation of the Slovenian electricity distribution companies’, Energy Policy 32: 335-344.

Grabher, G. and Stark, D. (1998) 'Organising diversity: evolutionary theory, network analysis and post-socialism', in J. Pickles and A. Smith (eds.) Theorising Transition: The Political Economy of Post-Communist Transformations., pp. 54-75. London and New York: Routledge.

Graham, S. and Marvin, S. (2001) Splintering Urbanism: Networked Infrastructures, Technological Mobilities, and the Urban Condition. London and New York: Routledge.

Gray, D. (1995) Reforming the Energy Sector in Transition Economies: Selected Experience and Lessons. Washington, D.C.: World Bank. 
Hetherington, K. and Law, J. (2000) 'Theme issue: after networks', Environment and Planning D: Society and Space 18: 127-132.

Hughes, G. (1991) 'The energy sector and problems of energy policy in Eastern Europe', Oxford Review of Economic Policy 7: 77-98.

Hughes, T. P. (1993) Networks of Power: Electrification in Western Society, 1880-1930. Baltimore: Johns Hopkins University Press.

Hulpachová, M. (2007) 'RWE plans new pipeline: 'Gazela' to import Russian gas from line beneath Baltic Sea', The Prague Post, 23rd May, 2007.

IEA (International Energy Agency) (2005) Energy Policies of IEA Countries: The Czech Republic. Paris: OECD/IEA.

Jørgensen, P. (2002) 'Challenging Times for the Balkans', in M. Burdett (ed.) Central and Eastern Europe and FSU Electricity Prospects for 2002, pp. 15-16. London: Platts.

Kazakevicius, E., Schipper, L. and Meyers, S. (1998) 'The residential space heating problem in Lithuania', Energy Policy 26: 859-872.

Kennedy, D. (2002) 'Regulatory reform and market development in power sectors of transition economies: the case of Kazakhstan', Energy Policy 30: 219-333.

Klaassen (2001) 'The future of gas infrastructures in Eurasia', Energy Policy 29: 399-413

Klare, M. T. (2008) Rising Powers, Shrinking Planet. New York: Metropolitan Books.

Kočenda, E. and Cábelka, S. (1999) 'Liberalization in the energy sector in the CEE-countries: transition and growth', Osteuropa-Wirtschaft 44: 104-116.

Kopačka, L. (2000) 'Transformation of the Czech society and economy and energy industry', Acta Universitatis Carolinae - Geographica 29: 39-59.

Kornai, J. (1986) 'The soft budget constraint', Kyklos 39: 3-30.

Kovačević, A. (2004) Stuck in the Past: Energy, Environment and Poverty in Serbia and Montenegro. Belgrade: United Nations Development Programme.

Lackó, M. (1997) Do Power Consumption Data Tell the Story? Electricity Intensity and the Hidden Economy in Post-Socialist Countries. Luxembourg: International Institute for Applied Systems Analysis.

Lampietti, J. and Meyer, A. (2002) When Heat is a Luxury: Helping the Urban Poor of Europe and Central Asia Cope with the Cold. Washington, D.C.: World Bank.

Latour, B. (1997) 'On Actor Network Theory: a few clarifications', Accessed on 10.04.2008 at http://cibersociologia.com/web/index2.php?option=com_content\&do_pdf=1\&id=18.

Latour, B. (1999) 'On recalling ANT', in J. Law and J. Hassard (eds.) Actor Network Theory and 
After, pp. 15-25. Oxford: Blackwell.

Latour, B. (2005) Reassembling the Social: An Introduction to Actor-Network-Theory. Oxford: Oxford University Press.

Laurila, J. (2003) 'Transit transport between the European Union and Russia in light of Russian geopolitics and economics', Emerging Markets Finance and Trade 39: 27-57.

Law, J. and Bijker, W. E. (1992) 'Postcript: technology, stability, and social theory', in J. Law and W. E. Bijker (eds.) Shaping Technology/Building Society: Studies in Sociotechnical Change, pp. 291-308. Cambridge, Mass.: MIT Press.

Lemke, J. L. (2000) 'Material sign processes and emergent ecosocial organisation', in P. B. Andersen, C. Emmeche, N. O. Finnemann and P. V. Christiansen (eds.) Downward Causation, pp. 181-213. Aarhus: Aarhus University Press.

Lewis, R. (1979) Science and Industrialization in the USSR. New York: Macmillan.

McFarlane, C. and Rutherford, J. (2008) 'Political infrastructures: governing and experiencing the fabric of the city', International Journal of Urban and Regional Research 32: 363-374.

Mitchell, T. (2008) 'Rethinking economy’, Geoforum 39: 1116-1121.

Monstadt, J. (2007) 'Urban governance and the transition of energy systems: institutional change and shifting energy and climate policies in Berlin', International Journal of Urban and Regional Research 31: 326-343.

Murdoch, J. (1998) 'The spaces of actor-network theory', Geoforum 29: 357-374.

New Europe (2009) 'Estonian minister wants land route for Nord Stream', Accessed on 28.07.2007 at http://www.neurope.eu/view_news.php?id=76397.

O’Lear, S. (2004) 'Resources and conflict in the Caspian Sea', Geopolitics 9: 161-186.

Orlikowski, W. J. (1992) 'The duality of technology: rethinking the concept of technology in organizations', Organizational Science 3: 398-427.

Pallot, J. and Shaw, D. (1982) Planning in the Soviet Union. London: Croom Helm.

Pavlínek, P. and Pickles, J. (2000) Environmental Transitions: Transformation and Ecological Defence in Central and Eastern Europe. London and New York: Routledge.

PEEE (Platts Energy in East Europe) (2007) 'Jockeying for position and power in 2007', 5th January, 2007.

Pickles, J. (2010) 'The spirit of post-socialism: common spaces and the production of diversity', European Urban and Regional Studies ****.

Radio Free Europe/Radio Liberty (2009) 'Devil is in detail of EU energy strategy', Accessed on 23.04.2009 at 
http://www.rferl.org/content/EU_Energy_Goals_Appear_Stuck_In_The_Pipeline/1614423.ht $\mathrm{ml}$.

Redorbit.com (2005) 'President confirms Macedonia's interest in Bulgarian nuclear power project', Accessed on 19.12.2005 at http://www.redorbit.com/news/science/334519/president_confirms_macedonias_interest_in_b ulgarian_nuclear_power_project/.

Round, J. and Williams C. (2010) 'Coping with the social costs of "transition": everyday life in postSoviet Russia and Ukraine', European Urban and Regional Studies, ****.

Routledge, P. (2008) 'Acting in the network: ANT and the politics of generating associations', Environment and Planning D: Society and Space 26: 119-217.

Rutland, P. (1997) Lost Opportunities: Energy and Politics in Russia. Washington, D.C.: The National Bureau of Asian Research.

Sarker, S., Saonee, S. and Sidorova, A. (2006) 'Understanding business process change: an actornetwork perspective’, Journal of Management Information Systems 23: 51-86.

Sharp, J. P., Routledge, P., Philo, C. and Paddison, R. (2000) 'Entanglements of power: geographies of domination/resistance', in J. P. Sharp, P. Routledge, C. Philo and R. Paddison (eds.) Entanglements of Power: Geographies of Domination/Resistance, pp. 1-42. London and New York: Routledge.

Socor, V. (2007) 'Baltic Seabed Gas Pipeline Project: Far From a Done Deal', Accessed on 22.05.2007 at http://www.jamestown.org/edm/article.php?article_id=2372178.

Star, S. L. (1999) 'The Ethnography of infrastructure', American Behavioral Scientist 43: 377-391.

Stern, J. (2002) Security of European Natural Gas Supplies: The Impact of Import Dependence and Liberalization. London: Royal Institute of International Affairs.

Stern, J. and Davis, J. R. (1998) 'Economic reform of the electricity industries of Central and Eastern Europe', Economics of Transition 6: 427-460.

Stern, J. P. (1980) Soviet Natural Gas Development to 1990: the Implications for the CMEA and the West. Lexington: Lexington Books.

Upi.com (2009) 'Nabucco vs. South Stream', Accessed on 30.04.2009 at http://www.upi.com/Energy_Resources/2009/04/30/Nabucco-vs-South-Stream/UPI97671241097194/.

Ürge-Vorsatz, D., Miladinova, G. and Paizs, L. (2006) 'Energy in transition: From the iron curtain to the European Union', Energy Policy 34: 2279-2297.

Velody, M., Cain, M. J. G. and Philips, M. (2003) A Regional Review of Social Safety Net Approaches in Support of Energy Sector Reform. Washington, D.C.: US Agency for Inernational Development. 
von Hirschhausen, C. and Wälde, T. W. (2001) 'The end of transition: an institutional interpretation of energy sector reform in Eastern Europe and the CIS', Moct-Most: Economic Policy in Transitional Economies 11: 93-110.

Waller, M. (1998) 'Geopolitics and the environment in Eastern Europe', Environmental Politics 7: $29-52$.

Weber, M. (1968) Economy and Society: An Outline of Interpretive Sociology. New York: Bedminster Press.

Westphal, K. (2006) 'Energy policy between multilateral governance and geopolitics: whither Europe?' International Politics and Society 2006: 44-62.

World Bank (1999b) Privatization of the Power and Natural Gas Industries in Hungary and Kazakhstan. Washington, D.C.: World Bank.

Yergin, D. (2006) 'Ensuring energy security’, Foreign Affairs 85: 69-82. 